\title{
Evaluation of the geotourism potential of selected geological sites in the eastern part of the borderland between the Siedlce Upland and Kuków Plain
}

\author{
Ocena potencjału geoturystycznego wybranych stanowisk pogranicza wschodniej \\ części Wysoczyzny Siedleckiej i Równiny Łukowskiej
}

\section{Anna Orłowska*}

Maria Curie-Skłodowska University in Lublin, Faculty of Earth Sciences and Spatial Management, Department of Geoecology and Palaeogeography; al. Kraśnicka 2c, d, 20-718 Lublin, Poland; anna.orlowska@poczta.umcs.lublin.pl

* Corresponding Author
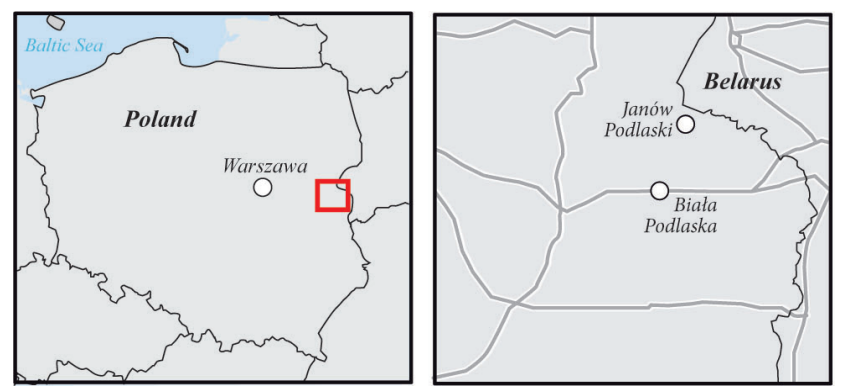

Article history:

Received: 23 January 2017

Accepted: 9 October 2017

Available online: 20 June 2018

(C) 2017 Authors. This is an open access publication, which can be used, distributed and reproduced in any medium according to the Creative Commons CC-BY 4.0 License requiring that the original work has been properly cited.

\begin{abstract}
Evaluating the geotourism potential of geological objects is now one of the main directions of geotourism development in Poland. So far, these have been usually carried out for famous and interesting objects, which are situated in physical-geographical regions of great morphological-geological values and are places of high intensity tourism. However, recently more and more attempts have been made to evaluate geotourism potential of geological objects situated in the areas considered unattractive to tourists. This paper reports the results of such an attempt, which has been made in the eastern part of the borderland between two physical-geographical regions of low-intensity tourism, i.e. the Siedlce Upland and Luków Plain. To evaluate the tourism potential of geological objects, the method of geosite evaluation has been used. The results allowed the author to distinguish the objects of high and unique scientific values, which may be proposed as geosites and a geotourist trail in the study area.
\end{abstract}

Key words: geotourism potential, evaluation of geosites, geotourist trail, Łuków Plain, Siedlce Upland

Treść: Ocena potencjału geoturystycznego obiektów geologicznych stanowi obecnie jeden z głównych kierunków rozwoju geoturystyki w Polsce. Dotychczas wykonywano ją najczęściej w przypadku znanych i ciekawych obiektów, znajdujących się w regionach fizycznogeograficznych o wysokich walorach morfologiczno-geologicznych, stanowiących miejsca charakteryzujące się intensywnym natężeniem ruchu turystycznego. Ostatnio jednak coraz czéściej podejmowane sa próby oceny potencjału geoturystycznego obiektów geologicznych, znajdujących się na obszarach uznawanych za mało atrakcyjne turystycznie. Taka próbę podjęto na obszarze pogranicza wschodniej części regionów fizycznogeograficznych Wysoczyzny Siedleckiej i Równiny Eukowskiej - regionów cechujących się mało intensywnym natężeniem ruchu turystycznego. Do oceny potencjału geoturystycznego wykorzystano metodę waloryzacji geostanowisk. Wyniki waloryzacji pozwolity na wyróżnienie obiektów o wysokiej, naukowej wyjątkowości, stanowiacej podstawę do utworzenia geostanowisk oraz szlaku geoturystycznego na analizowanym obszarze.

Stowa kluczowe: potencjat geoturystyczny, waloryzacja geostanowisk, geoturystyka, Równina Łukowska, Wysoczyzna Siedlecka 


\section{Introduction}

Evaluating the geotourism potential of geological objects in selected areas is now one of the main directions of geotourism development in Poland. So far, it has been carried out in the physical-geographical regions of great geological values, where interesting objects, being places of high intensity tourism, are situated. That is why the numerous published studies present the geotourism potential of mountain regions, which are recognised by tourists, e.g. the Sudetes (among others Knapik et al., 2009; Knapik \& Migoń, 2010; Cedro et al., 2009; Mianowicz \& Brzozowska, 2009; Różycka, 2014) or Carpathians (Kłapyta, 2015).

The geotourism potential of geological objects occurring in the physical-geographical regions of low intensity tourism, e.g. in the areas with lowland, flat relief and seemingly little interesting topographic features, has rarely been evaluated. Such features are typical mainly of the regions situated in Central Poland. They belong to the so-called old glacial area, which was formed by ice sheets of the Middle Polish Glaciations (from about 200000 to 130000 years ago) (sensu Lindner \& Marks, 2012). Łuków Plain and Siedlce Upland are such regions situated in eastern Poland. So far, their geotourism potential has not been evaluated for geotourism purposes.
The purpose of this study was to identify the geological resources in the eastern part of the borderland between two physical-geographical sub-regions (Siedlce Upland and Łuków Plain), and to indicate how they can be used in geotourism. This objective demanded the evaluation of selected geological sites representing different glacial landforms.

\section{Study area}

The evaluation of the geotourism potential of geological objects was made in the eastern part of the borderland between two physical-geographical mesoregions: Siedlce Upland and Łuków Plain (Fig. 1). According to the physicalgeographical regionalization of Poland published by Kondracki (2009), they belong to the South Podlasie Lowland region. It is mainly characterized by lowland (115-196 ma.s.1.Fig. 1), monotonous relief left by the last ice sheet of the Middle Polish Glaciations, i.e. the younger Saalian ice sheet, about 210 000-130 000 years ago (vide Mojski, 2005). However, the glacial origin of this area is of special nature. The boundary between the mentioned regions coincides approximately with the maximum extent of the younger Saalian ice front, which is marked by ridges and hills of end moraines arranged in trains and reaching 190-200 m a.s.l. (Fig. 1).



Fig. 1. Location of the selected geosites against the Digital Terrain Model of the eastern part of the borderland between the Siedlce Upland and Łuków Plain. The author's own study based on the Topographic Map of Poland, $1: 25000$. The maximum extent of the younger Saalian ice sheet line according to Godlewska 2014a and Mojski 1972); names of lobes according to Mojski (1972) and Terpiłowski (2000) 
The Siedlce Upland represents the inner zone of the ice front. Hills and ridges (mostly kames) occurring in this area reach 170-190 $\mathrm{m}$ a.s.l. The foreland of the ice front is a flat, sandy, outwash plain descending towards the SE from 170 to $140 \mathrm{~m}$ a.s.1., and belongs to the Łuków Plain. The described, the marginal zone of the younger Saalian ice sheet is characterized by sublatitudinal orientation and lobate shape. The evaluation of the selected geological objects, occurring within the extents of the Liwiec, Toczna and Klukówka ice lobes, was performed (Fig. 1). It was based on detailed morphological-geological investigations of surface deposits building glacial landforms (Godlewska, 2014a).

\section{Methods}

The evaluation of the geotourism potential of the selected sites was carried out using the method developed by Knapik et al. (2009) and Knapik \& Migoń (2010).

During the initial stage of the work, the geological sites were selected and inventoried. For this purpose the author's original materials were analysed, i.e. the monograph (Godlewska, 2014a), as well as the scientific papers and conference abstracts (Godlewska, 2007, 2008a, b; Godlewska
\& Terpiłowski, 2009a, b; Terpiłowski et al., 2009; Godlewska \& Terpiłowski, 2012; Godlewska, 2012, 2014a, b, 2015). Other materials concerning the study area were also useful in the evaluation. These were mainly scientific papers (among others Terpiłowski, 2000; Albrycht, 2004a), as well as geological and geomorphological maps (Brzezina, 2000; Dyjor \& Brzezina, 2000; Albrycht, 2004b). Based on all these materials, 16 sites were selected (exposures, quarries, opencast mines). All selected geological objects are glacial landforms, which have been identified and described with the use of lithofacies analysis (cf. Godlewska, 2014a).

The second stage of the work was the evaluation of the selected geological sites for geotourism purposes (according to Knapik et al., 2009 and Knapik \& Migoń, 2010). The following features of geosites were evaluated: scientific value, educational value, state of the object and dangers, and accessibility (Tab. 1). The evaluation was qualitative; each feature was evaluated in a scale $1-5$. The results are presented in Table 2.

In the final stage of the work the most interesting geosites, with the outstanding morphological and geological features, were selected in order to propose a geotourist trail (Orłowska, in preparation).

Tab. 1. Elements of geosite evaluation according to Knapik et al. (2009) and Knapik \& Migoń (2010)

\begin{tabular}{|c|c|c|}
\hline $\begin{array}{c}\text { Subject } \\
\text { of evaluation }\end{array}$ & Description & $\begin{array}{l}\text { Point } \\
\text { value }\end{array}$ \\
\hline \multirow{5}{*}{$\begin{array}{l}\text { Scientific } \\
\text { value }\end{array}$} & The only site in the region; unique in a mega-regional scale; presented in international scientific journals & 5 \\
\hline & Very important objects for regional studies; presented in national and international scientific journals & 4 \\
\hline & Object important for regional studies; presented in national and international scientific journals & 3 \\
\hline & Typical site of mediocre scientific value, presented in popular scientific magazines & 2 \\
\hline & No special distinguishing features; lack of publications & 1 \\
\hline \multirow{5}{*}{$\begin{array}{c}\text { Educational } \\
\text { value }\end{array}$} & Number of presented problems: 5 or more & 5 \\
\hline & Number of presented problems: 4 & 4 \\
\hline & Number of presented problems: 3 & 3 \\
\hline & Number of presented problems: 2 & 2 \\
\hline & Number of presented problems: 1 & 1 \\
\hline \multirow{5}{*}{$\begin{array}{c}\text { State of the } \\
\text { object }\end{array}$} & Well preserved, with no visible signs of degradation & 5 \\
\hline & Slightly disturbed structure of the site & 4 \\
\hline & Partially destroyed & 3 \\
\hline & Heavily changed by man & 2 \\
\hline & Destroyed, loss of geosite nature & 1 \\
\hline \multirow{5}{*}{ Accessibility } & Site situated directly on a tourist trail or nature trail & 5 \\
\hline & Site situated off the trail, but well visible from the trail, near a road or path & 4 \\
\hline & $\begin{array}{l}\text { Site not visible from the tourist trail and poorly visible from other points, situated more than } 500 \mathrm{~m} \\
\text { away from a road or path }\end{array}$ & 3 \\
\hline & Site difficult to access, e.g. overgrown or accessible by a route difficult to walk & 2 \\
\hline & Site inaccessible for tourists & 1 \\
\hline
\end{tabular}




\begin{tabular}{|c|c|c|c|c|c|c|c|c|c|c|c|c|c|c|c|c|}
\hline słu!od [вłoL & $\Xi$ & \pm & $\Xi$ & $\stackrel{\infty}{\sim}$ & $=$ & $a$ & $\simeq$ & $\simeq$ & $=$ & $=$ & $\mathscr{0}$ & $\simeq$ & $=$ & 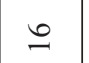 & 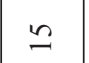 & $\Xi$ \\
\hline 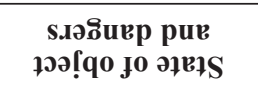 & in & in & $\nabla$ & $\sigma$ & $m$ & - & $m$ & $m$ & in & $m$ & $m$ & $m$ & $m$ & $m$ & in & $m$ \\
\hline 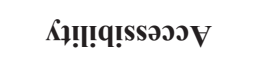 & + & n & m & 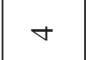 & $\sim$ & $\sim$ & m & n & m & m & m & m & 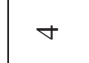 & m & 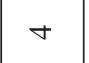 & n \\
\hline 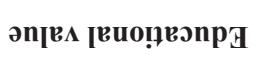 & n & n & n & in & n & m & n & n & n & n & n & n & in & in & m & in \\
\hline 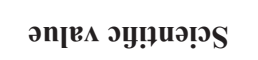 & N & n & $\diamond$ & in & n & m & n & n & 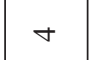 & $m$ & in & n & n & in & $m$ & $n$ \\
\hline 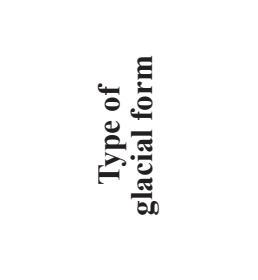 & 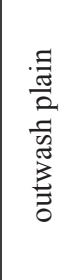 & 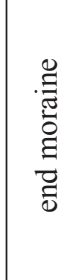 & 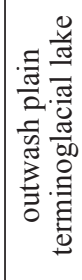 & 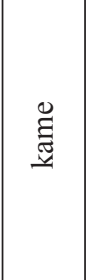 & 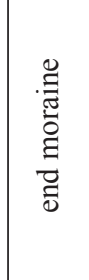 & 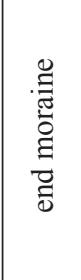 & 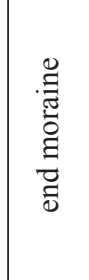 &  & 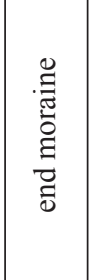 & 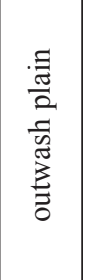 & 壹 & 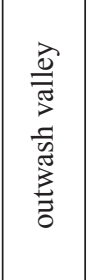 & 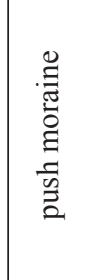 & $\begin{array}{l}\stackrel{\Xi}{\frac{\Xi}{2}} \\
\stackrel{\Xi}{\Xi}\end{array}$ & 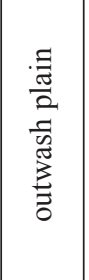 & 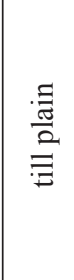 \\
\hline 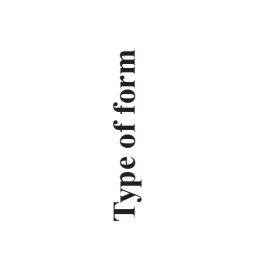 &  & 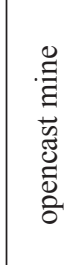 & 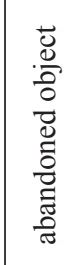 & 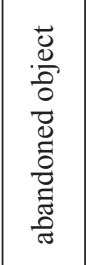 & 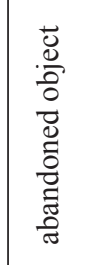 & 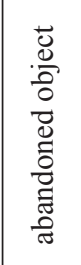 & 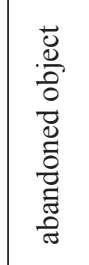 & 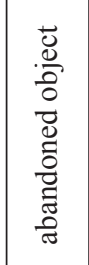 & 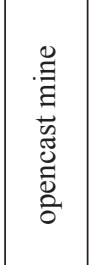 & 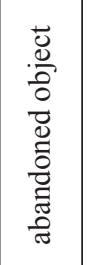 & 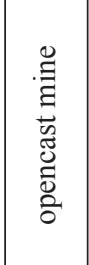 & 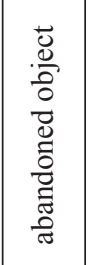 & 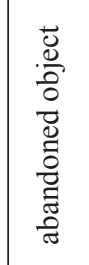 & 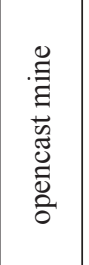 & 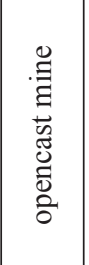 & 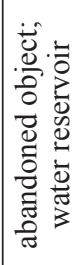 \\
\hline 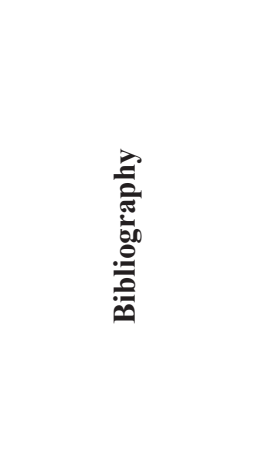 &  & 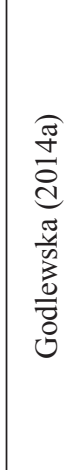 & 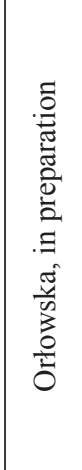 & 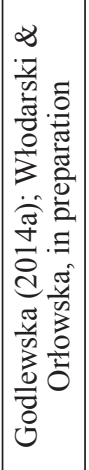 & 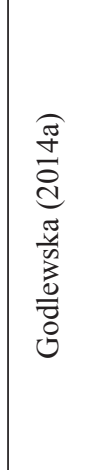 & 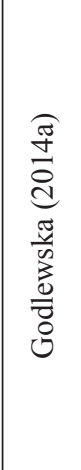 & 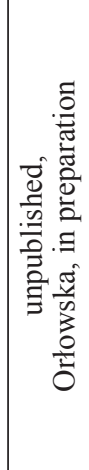 & 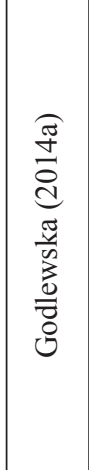 & 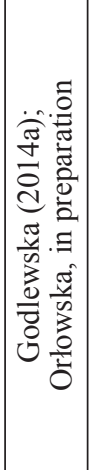 & 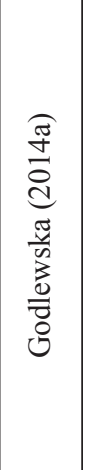 & 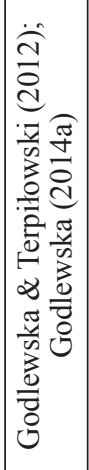 & 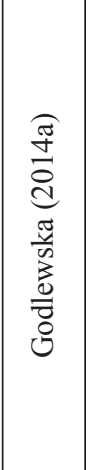 & 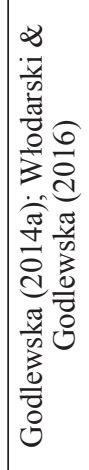 & 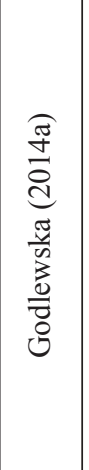 & 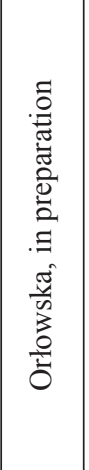 &  \\
\hline 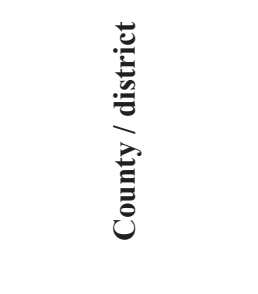 & 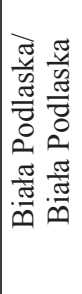 &  & 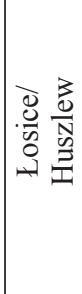 &  & 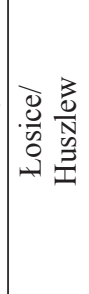 & 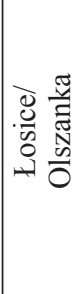 & 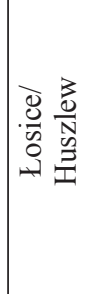 & 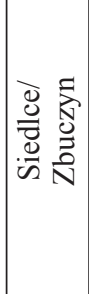 & 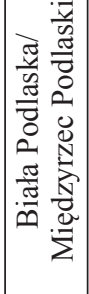 &  & 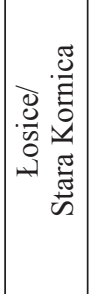 & 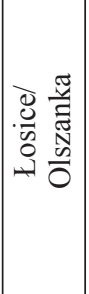 & 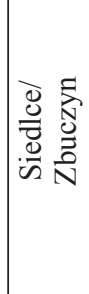 & 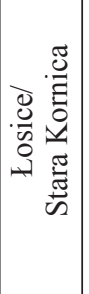 & 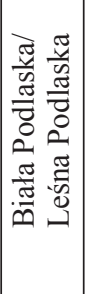 & 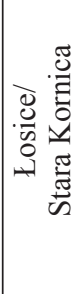 \\
\hline 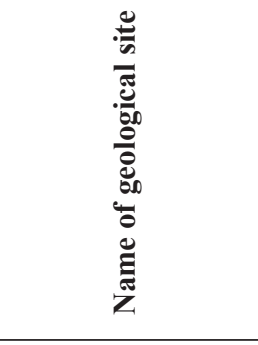 & 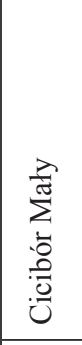 & $\begin{array}{l}\exists \\
: \begin{array}{l}0 \\
0\end{array} \\
0\end{array}$ & 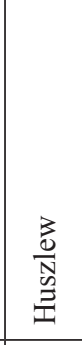 & $\begin{array}{l}\frac{\pi}{0} \\
\frac{0}{0} \\
\frac{0}{N}\end{array}$ & 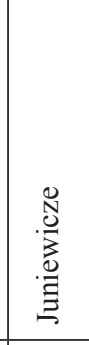 & 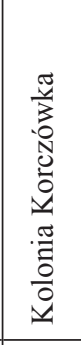 & 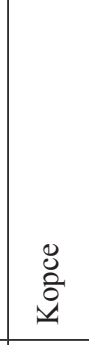 & 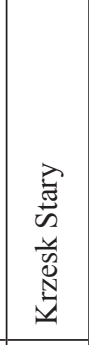 & 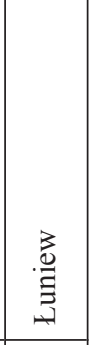 & $\begin{array}{l}\text { 辛 } \\
\text { 总 } \\
\sum_{0}^{0} \\
\end{array}$ & 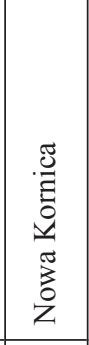 & 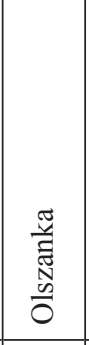 & $\begin{array}{l}0.0 \\
.0 \\
0 \\
0 \\
0\end{array}$ & 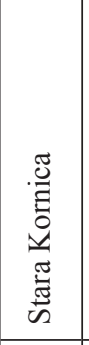 & 章 & $\begin{array}{l}\frac{4}{3} \\
\frac{0}{0} \\
3 \\
3\end{array}$ \\
\hline 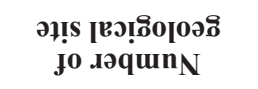 & - & $N$ & $m$ & $\sigma$ & in & 0 & $r$ & $\infty$ & $a$ & 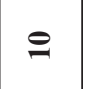 & $=$ & $\simeq$ & 2 & $\Xi$ & 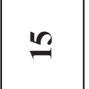 & 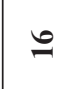 \\
\hline
\end{tabular}




\section{Evaluation}

\section{of the selected geological objects}

\section{Scientific values}

The results of the geosite evaluation indicate that the following geological sites have the greatest geotourism potential in terms of scientific value (five points): Izdebki, Nowa Kornica, Sobicze and Stara Kornica. Scientific dilemmas studied in these sites are very exceptional on a regional scale, unique on an mega-regional scale, and the results are published or worth publishing in international scientific journals.

Izdebki and Nowa Kornica sites represent the Pleistocene sequences of glaciolacustrine deposits (i.e. deposits of former post-glacial lakes). In the Izdebki site, the sequence is characterized by the occurrence of previously not described, atypical glacioisostatic deformations (Fig. 2), which indicate deposition at the bottom of the ice (Godlewska, 2014a; Włodarski \& Orłowska, in preparation), and in the Nowa Kornica site - well developed elements of the so-called fan delta (Fig. 3A; Godlewska \& Terpiłowski, 2012; Godlewska, 2014a). Such glaciolacustrine sequences are exceptionally rare in the Pleistocene deposits in Poland, Europe or North America.

Deposits of push moraine are found in the Sobicze site. These represent a unique example of simultaneous deposition and deformation of deposits (Fig. 4), which has not been found in push moraines in Poland so far (cf. Włodarski \& Godlewska, 2016).

Another object of exceptional scientific value is the Stara Kornica site where a sequence of deposits of different ages is exposed. This sequence has been deposited on the slope of a substratum bump and consists, from bottom to top, of Cretaceous chalk, Palaeogene sands, glaciofluvial and glacial deposits (Fig. 5). The most interesting unit is the youngest layer of till, composed of diamicton, with the packages of untypically dispersed chalk, which are unusual in diamictons. Chalk material was incorporated when the ice sheet was overriding the substratum bump. Then it was transported over a short distance and deposited on the distal slope.

The scientific value of the Huszlew and Luniew sites is lower than five (four points). Both sites are very important for regional studies, and the research results are to be published in national/international journals. Glaciolacustrine-glaciofluvial deposits occurring in the Huszlew site were deposited in the foreland of the ice sheet. This deposit sequence is evidence for the existence of a proglacial lake, the first one that has been found in eastern Poland. The Luniew site is an example of vast end moraine with the unique sequence of deposits, in which we can observe the traces of catastrophic floods of meltwater (Fig. 6A) and soft-sediment deformation structures (Fig. 6B) - rarely found in such landforms (Godlewska, 2014a).

Most sites have been classified as objects important for regional studies, the results of which are/can be presented in national journals (three points) (among others Godlewska, 2008a, b, 2015). These sites represent classic glacial landforms with typical deposit sequences, which are found in many areas covered by ice sheets in Pleistocene. End moraines with typical deposit sequences of glaciofluvial fans occur in the Droblin, Juniewicze, Kolonia Korczówka and Kopce sites. Outwash landforms with typical deposit sequences of braided rivers are exposed in the Krzesk Stary, Mostów, Olszanka and Witulin sites. The Wołowik site represents a moraine plateau with characteristic occurrence of till (Fig. 7A). However, this till is poorly developed as boulder pavement only (Fig. 7A, B).

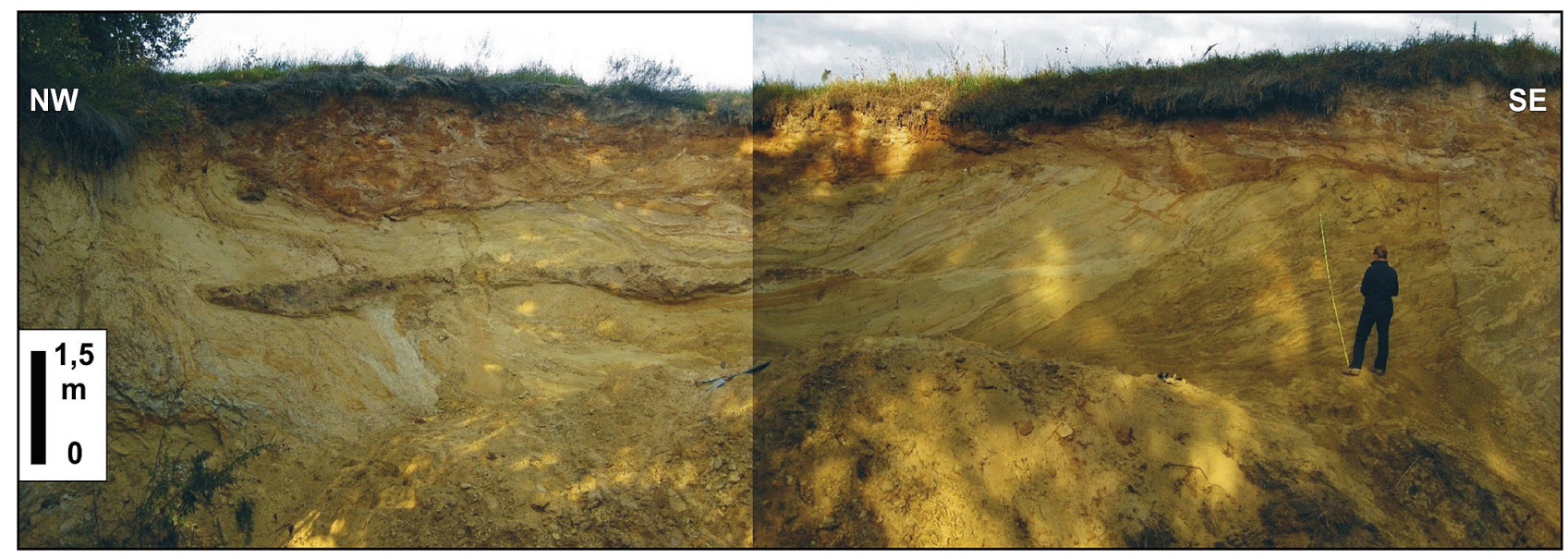

Fig. 2. Izdebki site: glacioisostatic deformations in form of syncline in the glaciolacustrine deposits, photo A. Orłowska 


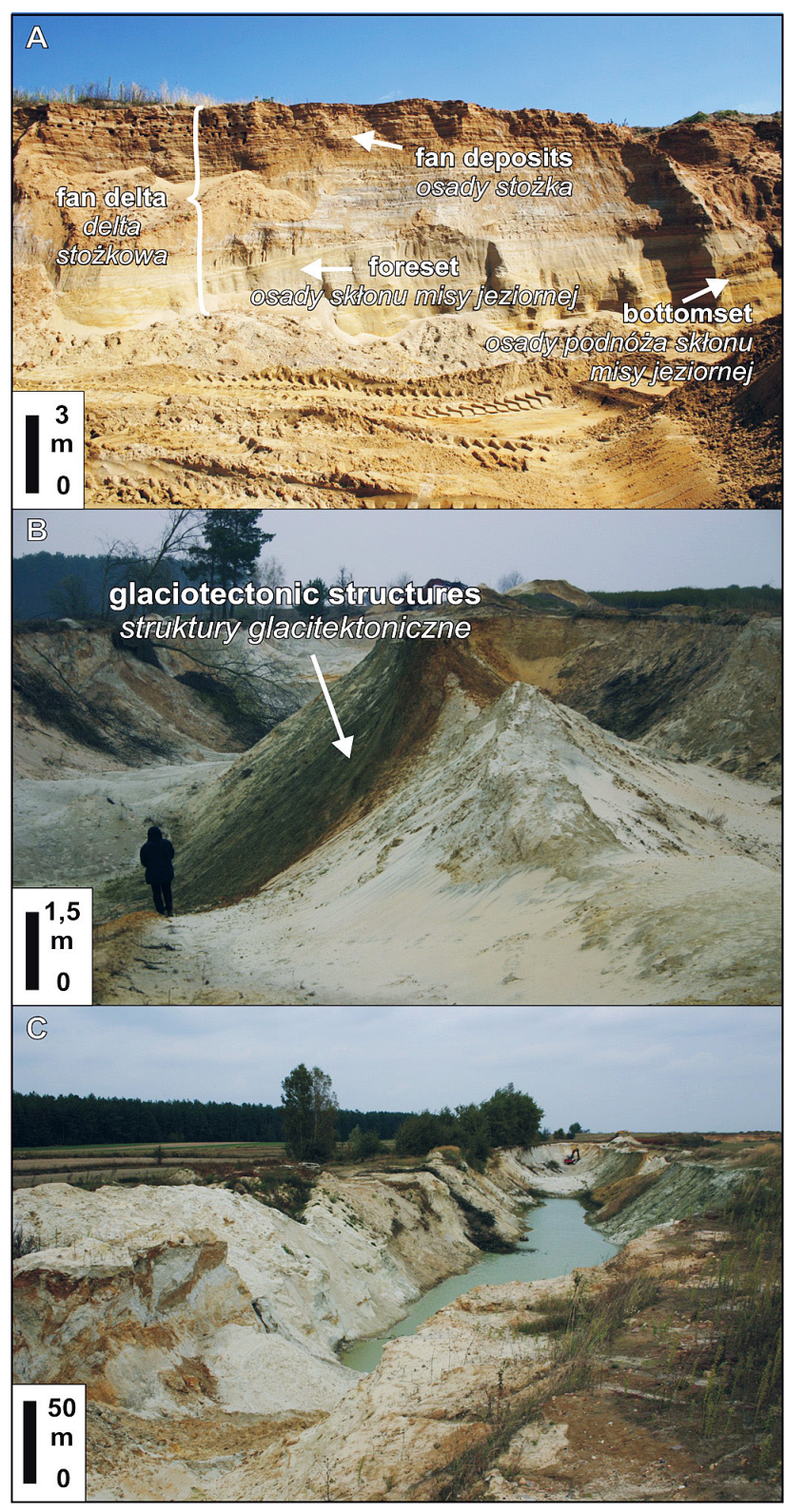

Fig. 3. Nowa Kornica site: A) Pleistocene sediments of fan-delta sequence; B) Palaeogene sands involved in glaciotectonic structures; C) chalk mine, photo A. Orłowska

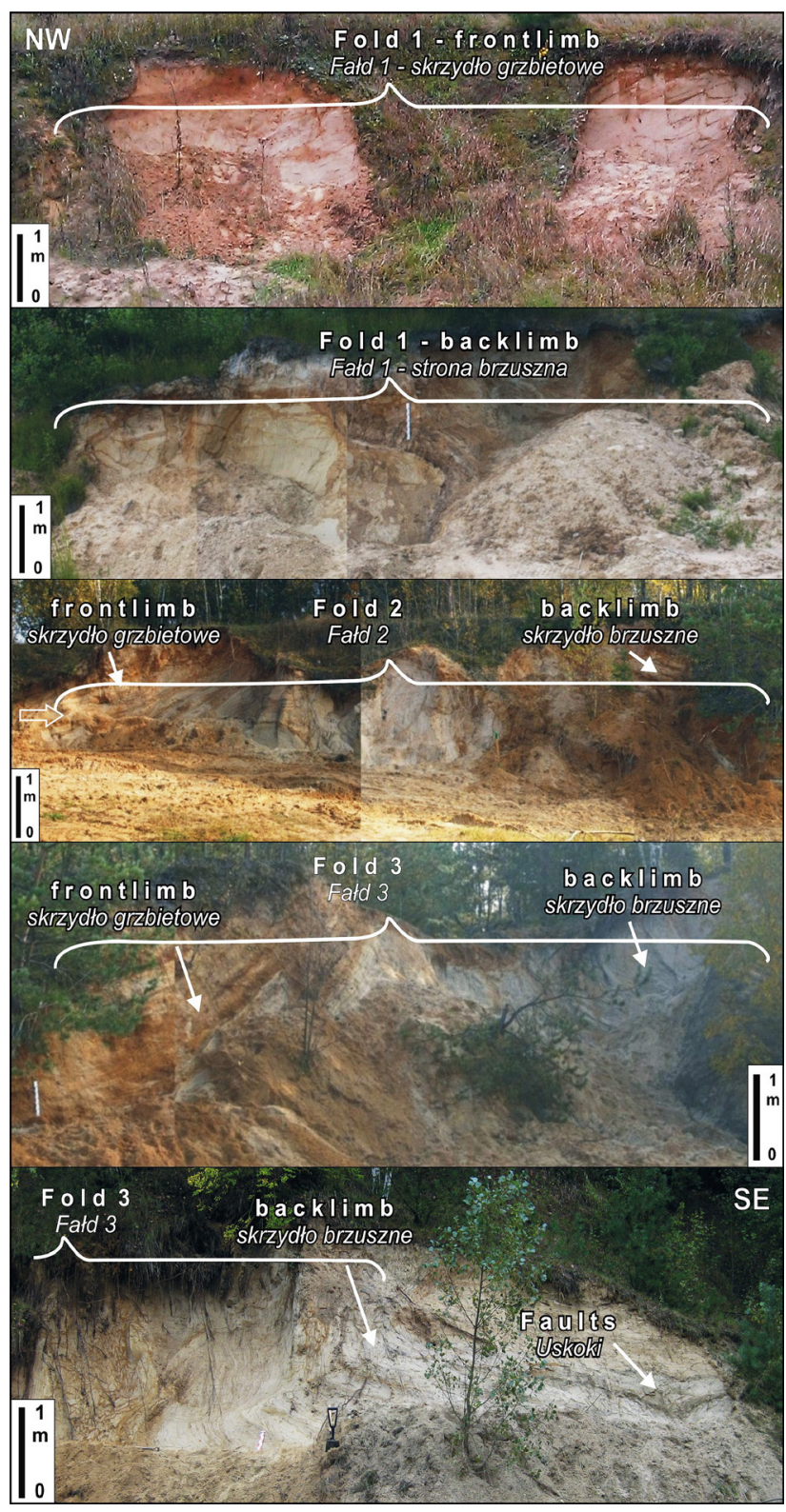

Fig. 4. Sobicze site: deformations of fan deposits in form of tree visible folds, photo A. Orłowska

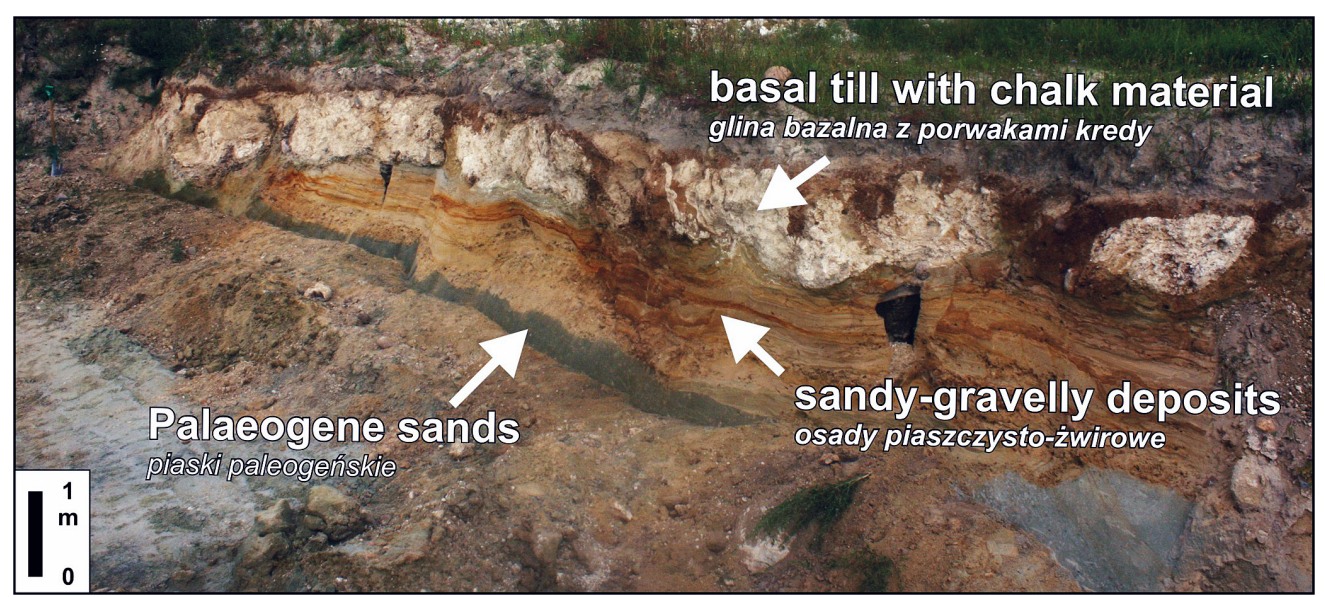

Fig. 5. Stara Kornica site - deposits of different age: Pleistocene younger Saalian glaciation basal till with incorporated chalk material, younger Saalian sands and gravels and Palaeogene sands, photo A. Orłowska 


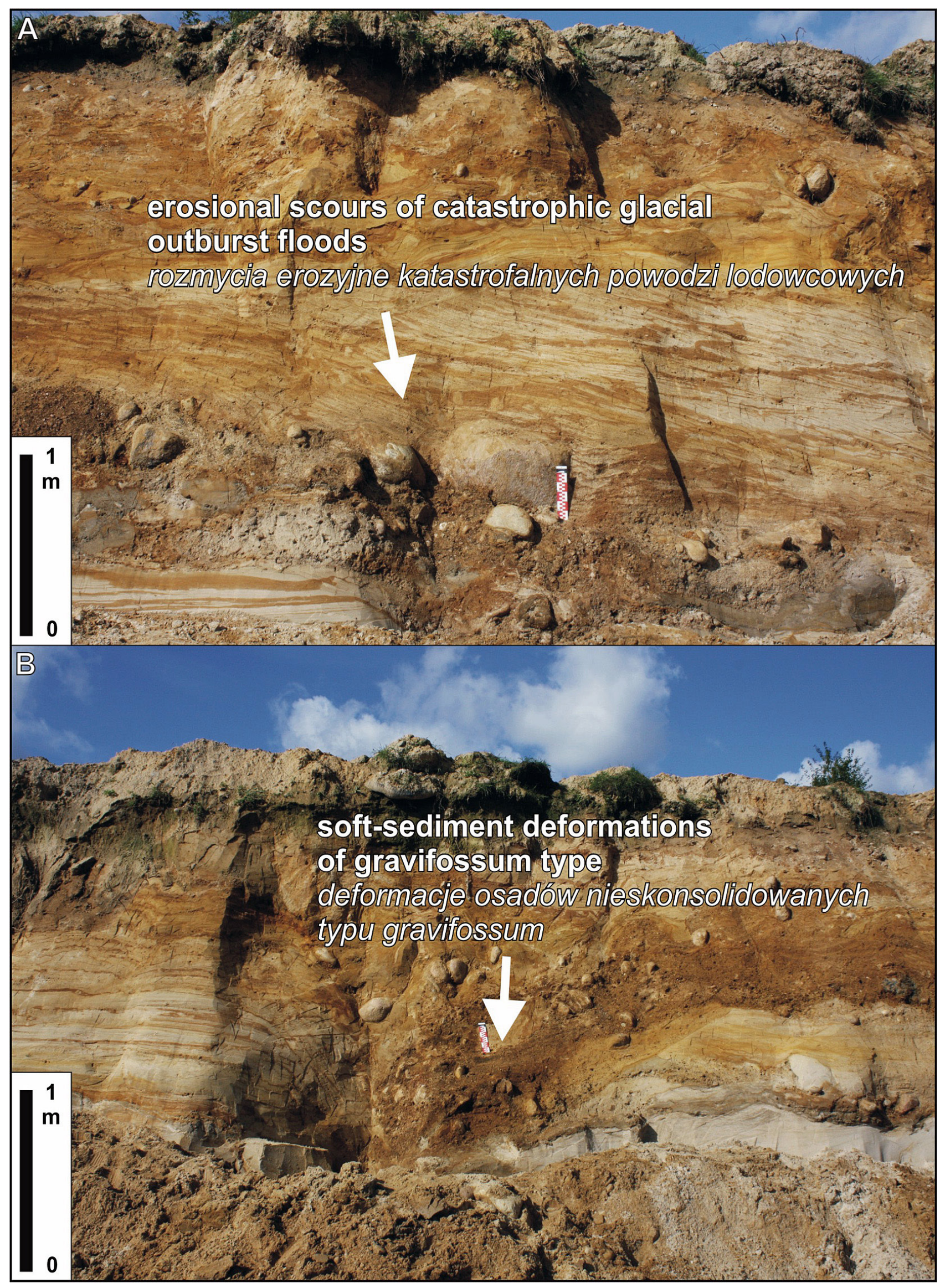

Fig. 6. Luniew site: A) deposits of catastrophic glacial outburst floods occurring rarely in end moraines; B) soft-sediment deformation structure of gravifossum type, photo A. Orłowska 


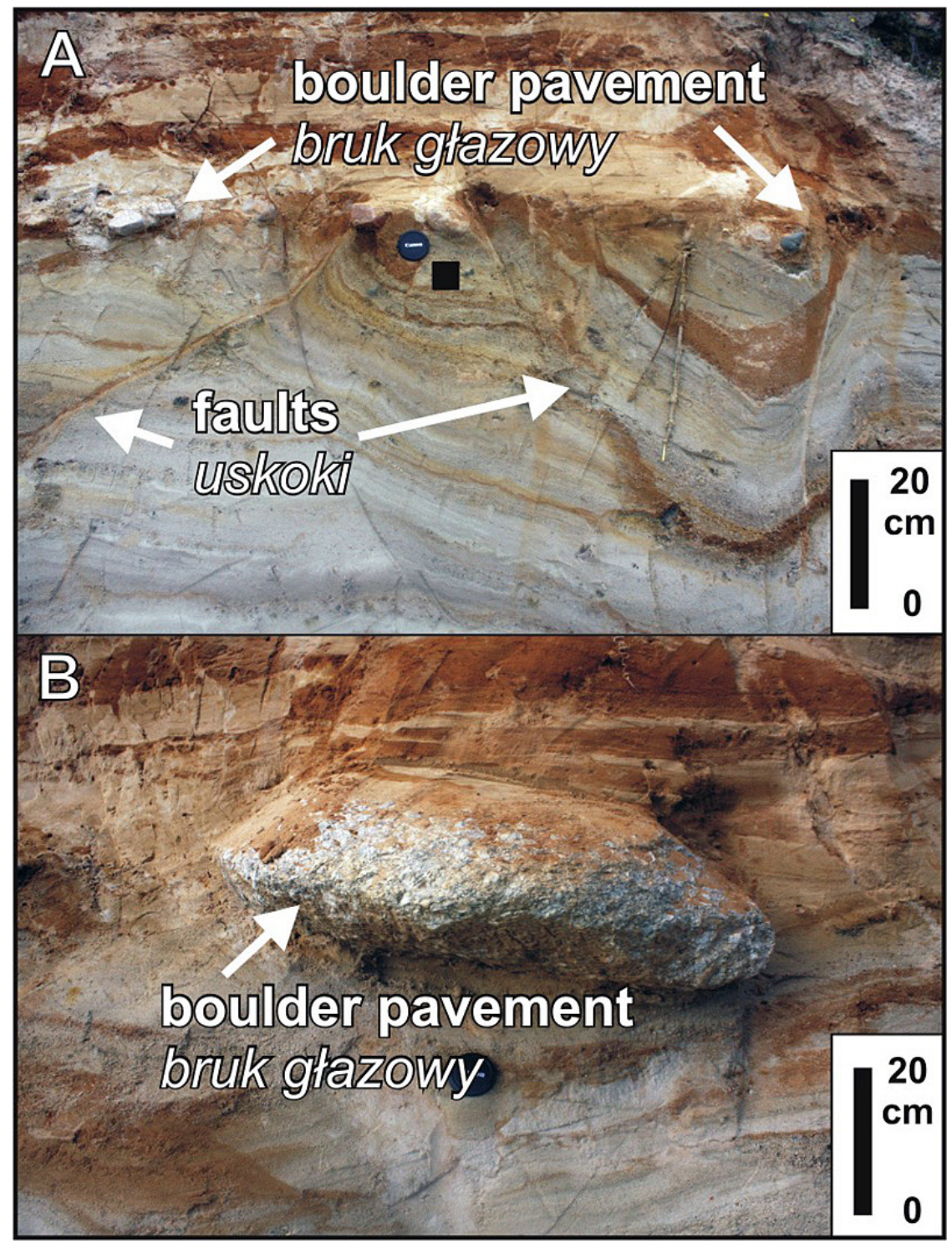

Fig. 7. Wołowik site: A) basal till in form of boulder pavement and thin layer of diamictite sands and deformation structures i.e. faults in the deposits that underlay the basal till; B) a large-size clast in the boulder pavement, photo A. Orłowska

\section{Educational value}

The analysis of the educational value of the selected geological sites indicates their high usefulness for the explanation of phenomena and processes occurring in the world of inanimate nature. As many as six sites received the maximum number of points according to the used method of evaluation. Moreover, no site was classified in the lowest classes.

The exposures of the greatest educational value, presenting at least five problems (five points), occur in the Izdebki, Łuniew, Nowa Kornica, Sobicze, Stara Kornica, and Wołowik sites.

The Izdebki and Nowa Kornica sites represent common glaciolacustrine landforms, i.e. kames. However, these kames are atypical as they contain the sequences of glaciodeltaic deposits, including the unique deposits of a fan delta (Fig. 3A) in Nowa Kornica. In Izdebki, on the other hand, we can observe glacioisostatic deformations. Moreover, these deposits are evidence of areal deglaciation. Different locations of the kames - on the substratum bump (Nowa Kornica), and on the edge of the fossil valley of the pre-Liwiec River (Izdebki) - are also interesting. In the Nowa Kornica site, older deposits are also exposed involved in glaciotectonic structures (Fig. 3B): Palaeogene sands (Fig. 3B) and chalk (Fig. 3C), which were formed during the advances of older ice sheets (cf. Albrycht, 2004a). Based on the Izdebki exposure, it is possible to determine the melting rate of ice-cored morainic ridges (vide Włodarski \& Orłowska, in preparation). 
In the Łuniew site, we can observe end moraine with an atypical sequence of deposits, which was formed as a result of catastrophic floods of meltwater (Orłowska, in preparation). The occurrence of large glaciofluvial fan is evidence of the conditions of a stationary ice front. This fan is composed of unconsolidated deposits with exposed soft-sediment deformations, which are rarely found in eastern Poland.

The Sobicze site represents the sequence of deposits deformed by glacial push and forming push moraine. Rarely observable deformation structures are exposed in the site. They indicate the occurrence of an advancing ice sheet. In this case, the ice sheet advanced along the fossil valley of the pre-Liwiec River (cf. Włodarski \& Godlewska, 2016) simultaneously with the processes of deposition and deformation.

The Stara Kornica site represents the moraine plateau. Its atypical profile is only up to $2 \mathrm{~m}$ thick, and consists, from bottom to top, of chalk, Palaeogene sands, glaciofluvial deposits and till. A special feature of this till is its lithology. It is a glacial diamicton with the packages of untypically dispersed chalk. Deformations of the underlying deposits indicate a rapid advance of the ice sheet. This rapid movement was favoured by a distal inclination of slope, along which the ice sheet advanced after overriding the substratum bump.

In the Wołowik site, the following geological objects and/or scientific problems can be presented: 1) moraine plateau situated on the slope of substratum bump, 2) sequence of till, which is poorly developed as boulder pavement, and 3) deformations indicating the rapid advance of ice sheet, favoured by distal inclination of substratum.

The educational value of most sites has been evaluated at 3 points. In each site three geological objects and/or problems can be discussed: 1) glacial landform, 2) deposit sequence (typical of a given landform), which gives evidence 3 ) to the dynamics of the ice-sheet front (decisive for the formation of a given type of landform).

End moraines occur in four sites, i.e. in Droblin, Juniewicze, Kolonia Korczówka, Kopce. The deposit sequences exposed in these sites represent a glaciofluvial fan dominated by sheet flows and/or channel flows. They demonstrate the conditions of a stationary ice-sheet front during its maximum advance or frontal recession.

Typical outwash landforms are exposed in five sites. Outwash valleys occur in Krzesk Stary, Olszanka and Witulin, while outwash plains can be observed in Cicibór Mały and Mostów. The exposed sediments were deposited in the environment of alluvial plains of braided rivers, and indicate stationary conditions or frontal recession of ice-sheet front during their deposition.

\section{Accessibility}

None of the analysed 16 sites has the good accessibility (five points), i.e. none is situated directly on a tourist or nature trail.

The following sites are easily accessible (four points): Cicibór Mały and Witulin in Biała Podlaska County, as well as Izdebki and Sobicze in Siedlce County.

The Cicibór Mały site is situated near the Trail of Old Churches and Manor Houses. Despite easy accessibility to the object from the trail (potentially five points), its valuation is lower because the trail is not thematically connected with natural objects. This is a typical cultural trail showing the historical heritage of the region. Probable inclusion of the Cicibór Mały geosite in the existing trail will be possible only after the transformation of the cultural trail into a cultural and nature trail. Many more natural objects presenting other problems should be included in this trail.

The Witulin site is situated not far from a bike trail The Beauty of Nature in the Podlasie Region, and the Izdebki and Sobicze sites - near the Korczew Bike Trail. Their proximity to the existing trails (up to $500 \mathrm{~m}$ ) creates a chance to include them in the mentioned trails through the adaptation of the objects for tourist presentation and the construction of access roads.

The following sites, situated far from the existing tourist trails and more than $500 \mathrm{~m}$ away from a road or path, and have been evaluated at three points: Droblin, Huszlew, Juniewicze, Kolonia Korczówka, Kopce, Krzesk Stary, Łuniew, Mostów, Nowa Kornica, Olszanka, Stara Kornica, Wołowik. Some of these sites are inactive opencast mines, but their adaptation for geotourism purposes is possible. Several sites have already been adapted (e.g. Juniewicze, Kopce) by digging new exposures situated next to the old abandoned pits.

None of the analysed objects was evaluated at two points (site difficult to access, e.g. overgrown) or at one point (site inaccessible for tourists). Therefore, all sites have geotourism potential in terms of their accessibility, and can be used for geotourism purposes in the future.

\section{State of the object and dangers}

The state of the preservation of the analysed objects differs. The best preserved exposures, without visible traces of degradation (five points), occur in the Cicibór Mały, Droblin, Łuniew, and Witulin sites. These sites are active opencast mines, so the preservation of exposures is threatened by the exploitation of raw materials. However, some 
walls are currently excluded from exploitation and not reclaimed, so they are accessible to tourists.

In the Huszlew and Izdebki sites, the structure of exposures is slightly destroyed, so their state of preservation has been evaluated at four points. These sites have not been exploited for a long time, but sometimes local people take raw materials from the pits, so that the exposed fragments of walls can be used for the establishment of geosites.

The partially destroyed exposures (three points) occur in the Juniewicze, Kopce, Krzesk Stary, Mostów, Olszanka, Sobicze, and Wołowik sites. In most sites (Juniewicze, Kopce, Krzesk Stary, Mostów, Sobicze), some walls are reclaimed, while the exposures in the Olszanka and Wołowik sites are filled with water. However, some fragments of walls are exposed in all these sites, and the deposit sequences will be clearly visible after a small cleaning of the walls. Therefore, the mentioned exposures are suitable to establish geosites, the more so because they are not exploited. Thus, it will be possible to adapt the exposures for tourists, set up information boards and permanent constructions protecting the exposures.

Another situation occurs in the Nowa Kornica and Stara Kornica sites. In these sites the exploitation is still continued, so the exposed structures (the deposits of unique fan-delta depositional environment in Nowa Kornica, and the sequence of Cretaceous, Palaeogene and Quaternary deposits in Stara Kornica) are gradually destroyed. At present only the fragments of formerly complete deposit sequences are visible.

The poorest preserved exposure (one point) occurs in the Kolonia Korczówka site. In recent years, the exposure has been heavily altered by man, reclaimed, and partially buried. Thus, it is now not suitable to establish geosite.

\section{Results of evaluation as the basis for proposing geotourist trail}

Based on the evaluation of geosites, the most interesting geological sites have been selected in order to propose a geotourist trail. These geosites show a high diversity of the inanimate nature in the eastern part of the borderland between Siedlce Upland and Łuków Plain.

The Izdebki site has the greatest geotourism potential (18 points; vide Table 2) due to its high scientific and educational values, as well as good accessibility and state of preservation. Four other sites are also very interesting in respect of scientific and educational values, but they are less accessible and poorly preserved, so their geotourist potential is lower: Łuniew and Sobicze sites (17 points), Nowa Kornica and Stara Kornica sites (16 points).

The mentioned objects are suitable for the presentation of a wide range of issues in the field of geology and geography, and due to their educational values, they should be made available for tourists. As they are located close to each other, the best form of their presentation is geotourist trail.

The proposed trail (Orłowska, in preparation) will include the geosites with the greatest geotourism potential. It will be supplemented with several additional sites presenting basic issues of geomorphology and glacial geology, which are located in the proximity of main geosites, so it will be possible to conveniently plan a trip route.

The trail will be routed from west to east. The sites will be divided into three groups belonging to some fragments of the marginal zone of the younger Saalian ice sheet, i.e. the Liwiec, Toczna and Klukówka ice lobes.

The westernmost group of sites (Łuniew, Sobicze and Izdebki) is situated in the marginal zone of the Liwiec lobe. The exposures will present the stages of development of glacial relief during the following dynamic states of the lobe (Fig. 8):

- stabilization of the ice front (Luniew site - Fig. 8A);

- retreat of the ice front (Fig. 8B), which was interrupted by a short advance (Sobicze site - Fig. 8C);

- areal deglaciation (Izdebki site - Fig. 8D).

Three sites situated in the marginal zone of the Toczna lobe will present the successive stages of development of glacial landforms during the following dynamic states of the lobe (Fig. 9):

- stabilization of the ice front (Juniewicze and Mostów sites - Fig. 9A);

- stabilization and retreat of the ice front (Olszanka site - Fig. 9B).

According to the results of evaluation, the development of glacial relief in the marginal zone of the Klukówka lobe will be best presented in the Nowa Kornica and Stara Kornica sites. Additional valuable information is recorded in the deposits of the Droblin and Cicibór Mały sites. The exposures will present the stages of development of landforms during the following dynamic states of the lobe (Fig. 10):

- advance of the ice front (Stara Kornica site Fig. 10A);

- stabilization of the ice front (Droblin and Cicibór Mały sites - Fig. 10B);

- areal deglaciation (Nowa Kornica site - Fig. 10C).

The detailed route of the geotrail with explanations will be presented in another publication (Orłowska, in preparation). 

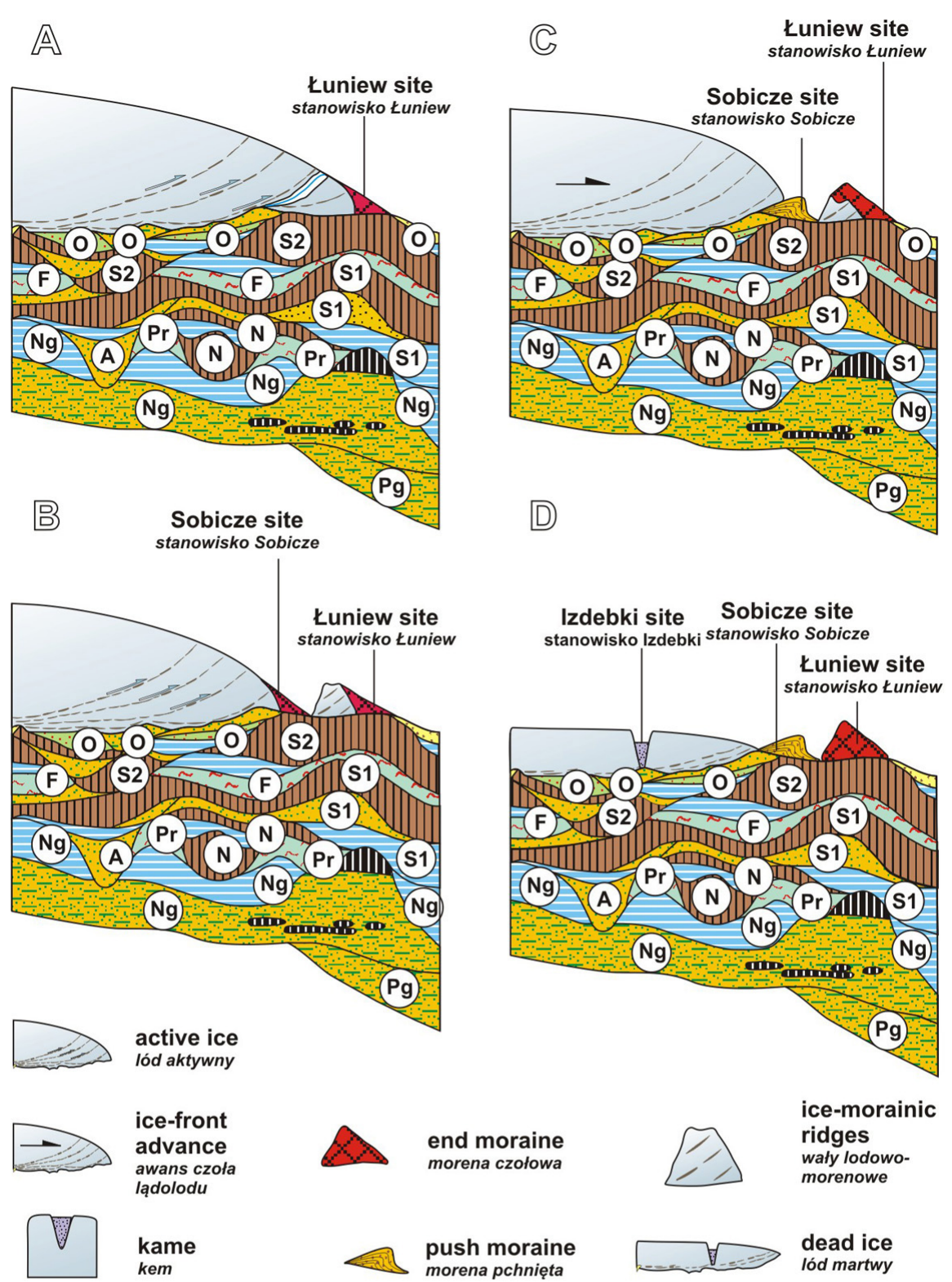
0 - older Saalian glaciation zlodowacenie odry
S2 - Elsterian glaciation zlodowacenie sanu 2
F - Cromerian interglacial interglacjał ferdynandowski
$\mathbf{S 1}$ - younger Cromerian glaciation zlodowacenie sanu 1
$\mathbf{N}$ - older Cromerian glaciation zlodowacenie nidy
A - Bavel interglacial interglacjał augustowsk
Pr - Preglacial preglacjat
$\mathrm{Ng}$ - Neogene
neogen
$\mathrm{Pg}$ - Paleogene paleogen

Fig. 8. The stages of relief development in the marginal zone of the Liwiec lobe (after Godlewska 2014a): A) stabilization of the ice front; B) retreat of the ice front; C) a short advance of the ice front; D) areal deglaciation 

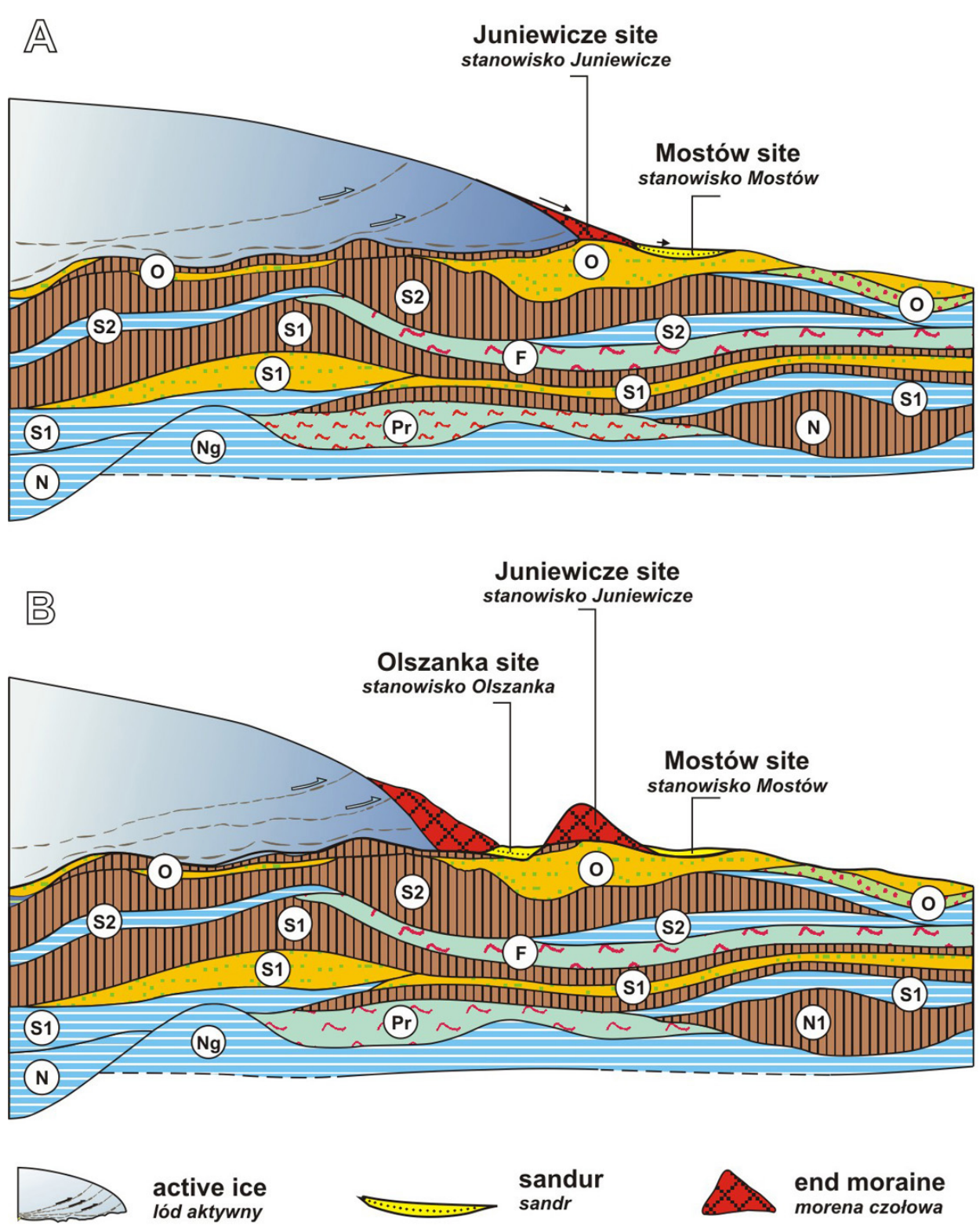

O - older Saalian glaciation zlodowacenie odry

S2 - Elsterian glaciation zlodowacenie sanu 2

F - Cromerian interglacial interglacjał ferdynandowski

$\mathbf{S 1}$ - younger Cromerian glaciation zlodowacenie sanu 1

$\mathbf{N}$ - older Cromerian glaciation zlodowacenie nidy

Pr - Preglacial preglacjał

$\mathrm{Ng}$ - Neogene

neogen basal till

glina zwałowa

\section{sands and gravels} piaski i żwiry sands piaski

silts

mułki

fines and silts

iły i mułki

Fig. 9. The stages of relief development in the marginal zone of the Toczna lobe (after Godlewska 2014a): A) stabilization of the ice front; B) stabilization and retreat of the ice front 


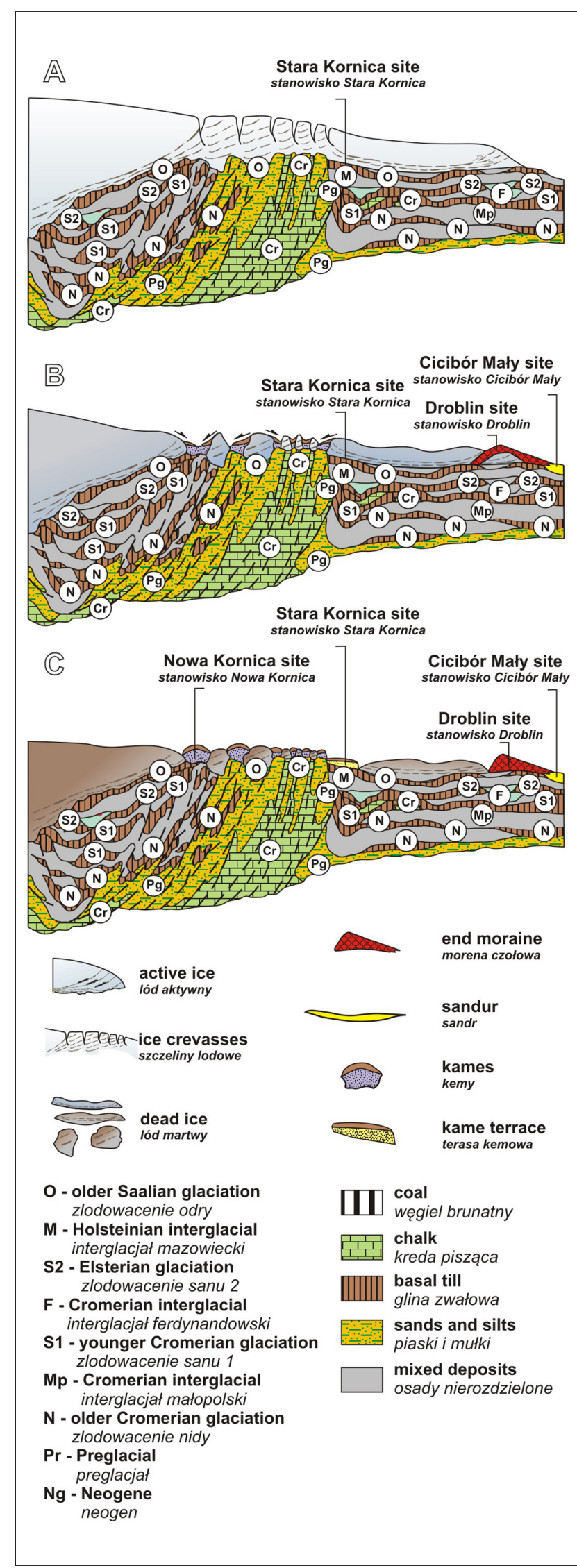

Fig. 10. The stages of relief development in the marginal zone of the Klukówka lobe (after Godlewska 2014a): A) advance of the ice front; B) stabilization of the ice front; C) areal deglaciation

\section{Conclusions}

The evaluation of geological objects, which has been carried out in the eastern part of the borderland between the Siedlce Upland and Łuków Plain, leads to the following final remarks and conclusions:

- The seemingly unattractive old glacial areas, with monotonous, flat landscapes, have interesting, unexplored values that can be successfully used in the promotion of physical-geographical regions, in nature tourism, or in the education of children and youth nationally, regionally or locally. The studied eastern part of the borderland between the Siedlce Upland and Łuków Plain is undoubtedly such an area. It is indicated by the results of the evaluation of the geotourism potential of the selected geological objects situated in this area.

- The analysis of scientific value of the studied geological objects indicates that they are not only the examples of commonly found and typical glacial landforms. The problems studied in a few exposures are exceptional in regional scale, unique in mega-regional scale, and the results are published or worth publishing in international scientific journals. The analysis of the educational value of these geosites indicates their high usefulness for the explanation of phenomena and processes occurring in the world of inanimate nature.

- The accessibility and state of preservation of the studied geosites are not very good, but do not prevent the promotion of their geotourism potential. The proposed geotourist trail will facilitate access to the individual objects and improvement of their state of preservation. This form of tourist presentation is a good way to prevent potential dangers, including natural overgrowing or anthropogenic reclamation of the exposures.

- The method of evaluating of the geological objects makes it possible to estimate the geotourism potential of the studied physical-geographical region. The obtained results can be successfully used in the preparation of geotourist offer in eastern Poland.

\section{Acknowledgements}

This work was financed from Statutory Funds of Department of Geoecology and Palaeogeography in Faculty of Earth Sciences and Spatial Management of Maria Curie-Sktodowska University in Lublin. The author thanks to Reviewers for constructive comments which improved the manuscript. 


\section{References (Literatura)}

Albrycht A., 2004a. Strefa marginalna lądolodu zlodowacenia warty w okolicy Kornicy (Wysoczyzna Siedlecka). In: Harasimiuk M., Terpiłowski S. (eds), Zlodowacenie warty w Polsce. Wydawnictwo UMCS, Lublin: 135-152.

Albrycht A., 2004b. Szczegółowa mapa geologiczna Polski w skali 1 : 50000, ark. Sarnaki wraz z objaśnieniami. PIG, Warszawa.

Brzezina R., 2000. Szczegółowa mapa geologiczna Polski 1 : 50 000, ark. Krzesk wraz z objaśnieniami. PIG, Warszawa.

Cedro B., Mianowicz K. \& Zawadzki D., 2009. Ocena walorów geoturystycznych stanowisk pochodzenia wulkanicznego Gór i Pogórza Kaczawskiego. In: Dudkowski M. (ed.), Problemy turystyki i rekreacji, 2. Oficyna IN PLUS, Szczecin: 25-35.

Dyjor K. \& Brzezina R., 2000. Szczegółowa mapa geologiczna Polski w skali 1 : 50 000, ark. Swory wraz z objaśnieniami. PIG, Warszawa.

Godlewska A., 2007. Rozwój strefy marginalnej lobu Tocznej zlodowacenia warty (Nizina Południowopodlaska). In: XIV Konferencja „Stratygrafia plejstocenu Polski”, 3-7 września 2007, Ciechocinek, 105-106.

Godlewska A., 2008a. Mechanizm kształtowania strefy marginalnej lobu Tocznej lądolodu warciańskiego (Nizina Południowopodlaska). Annales UMCS, sec. B, 63: 131-146.

Godlewska A., 2008b. Geneza kemów lobu Tocznej lądolodu warciańskiego (Nizina Podlaska). Landform Analysis, 9: 143-145.

Godlewska A., 2012. Zanik lądolodu warty na międzyrzeczu Krzny i Bugu (wschodnia Polska). XIX Konferencja ,Stratygrafia plejstocenu Polski”, Cedynia, 3-7.09.2012. Materiały. Państwowy Instytut Geologiczny, Państwowy Instytut Badawczy, Warszawa, 123.

Godlewska A., 2014a. Dynamika ladolodu warty w strefie marginalnej na międzyrzeczu Krzny i Bugu w świetle analizy litofacjalnej. Wydawnictwo UMCS, Lublin.

Godlewska A., 2014b. Rozwój strefy marginalnej lądolodu warty w międzyrzeczu Krzny i Bugu w świetle analizy litofacjalnej. In: X Zjazd Geomorfologów Polskich. Materialy konferencyjne, 16-19 września 2014, Toruń, 46-47.

Godlewska A., 2015. Nowe spojrzenie na dynamikę lądolodu warty w strefie marginalnej na międzyrzeczu Krzny i Bugu (wschodnia Polska). Acta Geographica Lodziensia, 103: 45-56.

Godlewska A. \& Terpiłowski S., 2009a. Rzekome moreny martwego lodu lobu Liwca. In: Żarski M. \& Lisicki S. (eds), Strefa marginalna ladolodu zlodowacenia warty i pojezierza plejstoceńskie na poludniowym Podlasiu. XVI Konferencja „, Stratygrafia plejstocenu Polski”, Zimna Woda k. Łukowa, 31.08-4.09.2009. Materiaty. Państwowy Instytut Geologiczny, Warszawa, 159-162.

Godlewska A. \& Terpiłowski S., 2009b. Recesyjne moreny czołowe lobu Tocznej. In: Żarski M. \& Lisicki S. (eds), Strefa marginalna ladolodu zlodowacenia warty i pojezierza plejstoceńskie na poludniowym Podlasiu. XVI Konferencja „Stratygrafia plejstocenu Polski”, Zimna Woda k. Łukowa, 31.08-4.09.2009. Materiaty. Państwowy Instytut Geologiczny, Warszawa, 163-165.

Godlewska A. \& Terpiłowski S., 2012. Transverse, supraglacially derived crevasse infillings in a Pleistocene ice-sheet margin zone (eastern Poland): genesis and sedimentary record. Geomorphology, 161-162: 73-81.

Kłapyta P., 2015. Różnorodność walorów geologicznych i geomorfologicznych środkowej części Beskidu Niskiego i Pogórza Karpackiego jako podstawa dla rozwoju geoturystyki. In: Szpara K., Zawilińska B. \& Wilkońska A. (eds), Lokalny potencjat a zrównoważony rozwój turystyki w Karpatach. Centrum UNEP/GRID Rzeszów-Warszawa: 11-32.

Knapik R. \& Migoń P., 2010. Karkonoski Park Narodowy z otuliną jako geopark krajowy. Przeglad Geologiczny, 58: 1065-1069.

Knapik R., Jała Z., Sobczyk A., Migoń P., Aleksandrowski P., Szuszkiewicz A., Krąpiec M., Madej S. \& Krakowski K., 2009. Inwentaryzacja i waloryzacja geostanowisk Karkonoskiego Parku Narodowego i jego otuliny oraz wykonanie mapy geologicznej tego obszaru. Archiwum Karkonoskiego Parku Narodowego, Jelenia Góra.

Kondracki J., 2009. Geografia regionalna Polski. PWN, Warszawa,

Lindner L. \& Marks L., 2012. O podziale klimatostratygraficznym kompleksu środkowopolskiego w plejstocenie Polski. Przegląd Geologiczny, 60: 1-10.

Mianowicz K. \& Brzozowska K., 2009. Potencjał geoturystyczny Wojcieszowa (Góry Kaczawskie). In: Dudkowski M. (ed.), Problemy turystyki i rekreacji, 2. Oficyna IN PLUS, Szczecin: 19-23.

Migoń P., 2012. Geoturystyka. PWN, Warszawa.

Mojski J.E., 1972. Nizina Podlaska. In: Galon R. (ed.), Geomorfologia Polski, t. 2 Niż Polski. PWN, Warszawa: 318-363.

Mojski J.E., 2005. Ziemie polskie w czwartorzędzie. PIG-PIB, Warszawa.

Różycka M., 2014. Atrakcyjność geoturystyczna okolic Wojcieszowa w Górach Kaczawskich. Przeglad Geologiczny, 62: 514-520.

Terpiłowski S. (red.), 2000. Osady, struktury, deformacje i formy warciańskiej strefy glacjomarginalnej na Nizinie Podlaskiej. In: Terenowe Warsztaty Sedymentologiczne „, Osady, struktury deformacyjne i formy warciańskiej strefy glacjomarginalnej na Nizinie Podlaskiej”, Lublin-Mielnik, 24-29 wrzesień 2000. Materiaty. Wydawnictwo UMCS, Lublin.

Terpiłowski S., Albrycht A., Dobrowolski R. \& Godlewska A., 2009. Formy szczelinowe lobu Klukówki. In: XVI Konferencja „Stratygrafia plejstocenu Polski”, Zimna Woda k. Lukowa, 31.08-4.09.2009. Materiały. Państwowy Instytut Geologiczny, Warszawa, 166-172.

Włodarski W. \& Godlewska A., 2016. Sedimentary and structural evolution of a Pleistocene small-scale push moraine in eastern Poland: new insight into palaeoenvironmental conditions at the margin of advancing ice lobe. Quaternary Science Reviews, 146: 300-321. 